\title{
Journey into the Teaching Profession: Experiences of Classroom Teachers ${ }^{1}$
}

\section{Zeynep Kılıç}

Assistant Professor, Faculty of Education, Eskişehir Osmangazi University, Eskişehir, Turkey

https://orcid.org/0000-0002-5756-3782

\section{Nurhan Atalay}

Assistant Professor, Faculty of Education, Niğde Ömer Halisdemir University, Niğde, Turkey https://orcid.org/0000-0003-1002-3110

Volume: 9

Issue: 3

Month: June

Year: 2021

P-ISSN: $2320-2653$

E-ISSN: 2582-1334

Received: 27.03.2021

Accepted: 18.05.2021

Published: 01.06.2021

Citation:

Kılıç, Zeynep, et al.

"Journey into the Teaching

Profession: Experiences

of Classroom Teachers."

Shanlax International

Journal of Education, vol. 9, no. 3, 2021, pp. 186-195.

DOI:

https://doi.org/10.34293/

education.v9i3.3922

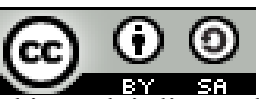

This work is licensed under a Creative Commons Attribution-ShareAlike 4.0 International License

\section{Burcu Anılan}

Associate Professor, Faculty of Education, Eskişehir Osmangazi University, Eskişehir, Turkey iD https://orcid.org/0000-0002-4153-1866

\section{Şengül S. Anagün}

Professor, Faculty of Education, Eskişehir Osmangazi University, Eskişehir, Turkey

\section{Hüseyin Anılan}

Professor, Faculty of Education, Eskişehir Osmangazi University, Eskişehir, Turkey

https://orcid.org/0000-0001-7201-7467

\begin{abstract}
The main purpose of this study was to reveal the experiences and problems faced by the classroom teachers who just started the teaching profession. The phenomenology approach was employed in the study since the study examined the experiences of classroom teachers who just started teaching by interviewing them. Sample selection was determined by using a purposeful sampling method to understand the phenomenon. In this regard, criterion sampling, one of the purposive sampling methods, was utilized in the study to obtain in-depth information about the phenomenon. Within the scope of the research, two basic criteria were taken into account, which is not being in the teaching profession for more than three years and working in schools with different socio-economic levels. The interviews were conducted online with the teachers at the times and dates determined by the teachers. The reason for conducting the interviews online was that the classroom teachers participating in the study worked in different cities. A total of 20 interviews were conducted, including classroom teachers from different regions of Turkey. Thematic analysis was used in the analysis of the study data. According to the results, classroom teachers in their first years, the study determined that teachers expressed their experiences in the context of "professional experiences" and "sociocultural-regional experiences."
\end{abstract}

Keywords: Classroom teachers, Teaching profession. Primary education, Professional experiences, Sociocultural-regional experiences, Phenomenology

1 This study was presented as an oral presentation of the conference "IV International Eurasian Educational Research Congress"
D https://orcid.org/0000-0002-8011-0730 


\section{Introduction}

In Turkey, faculties of education are responsible for the training of teachers who contribute the most to societies' development and the Ministry of Education is responsible for providing employment for them. It is important to provide teacher candidates with experiences in teaching practices in order for teaching's basic competencies and to make theoretical knowledge more meaningful. In this context, preparing teacher candidates to be successful in their first year of teaching should be the main goal of teacher training Beck, et al., (2007). No matter how well-trained individuals graduate from the teacher training programs, they face reallife problems after beginning their teaching careers. Unless the teacher candidates are confronted with the knowledge, skills, attitudes, and behaviors they will need in real educational environments and gain experience, the theoretical knowledge they receive will not mean much for them (Sarıtaş, 2007). The first years of the teaching profession is an important stage in which teachers encounter difficulties and problems the most and try to cope with these problems (Casey, 2005; Ingvarson, et al., 2007; Feiman-Nemser, 2003). Denscombe (1985) stated that the first year of teaching is key for the years to come.

Gold, Roth, Wright, and Michael (1991) expressed that the job of first-year teachers is difficult and stressful and that they carry a lot of workload on their shoulders that no one can imagine. The first year of teaching is considered as the "time to succeed or break." Transition to the teaching profession can be challenging for newcomers (Eaton \& Sisson, 2008). Some refer to the experiences of teachers who are left on their own in their classrooms for the first time in the early years of their profession as being lost at sea (Kauffman, et al., 2002; Johnson \& Birkeland, 2003). None of the teachers who just started the profession encountered situations that exactly match the expectations of their first year or do not know exactly how to cope with the difficulties they have experienced (Wyatt III \& White, 2007). A successful start is critical to both the teachers' careers and the education of the students. Positive experiences in the early years help teachers to build solid perspectives and approaches for the rest of their careers.
The success of teachers who are new to the profession should be of concern for everybody (Barbara \& Grady, 2007). First impressions are effective in the progress and success of teachers at the beginning of the profession. Opportunities for success at the beginning of the profession provide opportunities for advancement, while low levels of interest cause unsuccessful results. Studies revealed that teachers had an idealistic perspective during their teacher training years, whereas they encounter a traditional and conservative structure after starting their profession. Therefore, teachers who are new to the profession lose idealism and accept the existing structure (Zeichner \& Tabachnick, 1985; Lacey, 1988). The first year of teaching is a turning point for the teaching profession and an effort to survive. It may take a long time for classroom teachers who are new to the profession to positively solve the problems they encounter on their own. In this context, knowing the problems faced by classroom teachers in the first years of their profession will contribute to the solution of problems in a short time, as well as providing classroom teachers with the opportunity to cooperate with other stakeholders of the education system in solving problems. Thus, both professional success and individual development of classroom teachers will increase. In this regard, the main purpose of this study is to reveal the experiences and problems faced by the classroom teachers who just started the teaching profession.

\section{Literature Review}

Studies conducted on teachers determined that newly employed teachers experience confusion between their ideals and the realities they encounter in the school environment (Zeichner \& Tabachnick, 1985). The teaching profession has traditionally been characterized as a profession with a high level of burnout, especially among new teachers (Grissmer \& Kirby, 1987, 1997; Lortie, 1975; Veenman, 1985). While the burnout stemming from the profession may be due to the nature of the profession, one of the factors accelerating this process is the working conditions closely affected by the places the teachers are settled. In this regard, teacher burnout is particularly problematic in rural school districts struggling with initial recruitment difficulties (Barley, 
2009; Lowe, 2006). Young teachers are unlikely to work with an experienced colleague in schools in these regions. New teachers also do not get enough help from their colleagues in their professional socialization (Deal \& Chatman, 1989). In addition, the physical distance of rural communities and the separation from the existing social environment that was formed during the school years further strengthen the new teachers' sense of separation (Barley, 2009). In particular, challenges specific to rural schools can catch these new teachers unprepared (McCracken \& Miller, 1988; Fry \& Anderson, 2011). The teachers who work in rural areas should learn a particular culture not only from their new school but also from the rural community (Eppley, 2009). This learning process is not only challenging but also an important link enabling them to hold on to the profession.

Many studies also put forth that teachers who are new to the profession consider themselves inadequate and unprepared for classroom management (Britt, 1997; Jacques, 2000; Ladd, 2000; Savage \& Savage, 2010; Fideler \& Haskelhorn, 1999). Smith and Ingersoll (2004) stated that $15 \%$ of all new teachers quit teaching at the end of their first year. Moreover, the literature revealed that about $33 \%$ of all teachers leave the profession in the first three years of teaching and $50 \%$ in the first five years, and it takes four to seven years of experience for an individual to become a competent teacher (Carter \& Doyle, 1995; Gonzalez \& Carter, 1996; Varrella, 2000). Aydın and Şahin (2020) expressed that the most important factor in new elementary school teachers choosing practices to restore order is "the total time spent in the profession/professional experience." In this sense, experience comes to the forefront here, as in every point of life. It can be stated that seniority plays an active role in analyzing students' behaviors and developing effective coping methods.

\section{Material and Methods}

This phrenologic study aimed to reveal the experiences of classroom teachers who just started the teaching profession. Phenomenological studies try to understand the experiences of the participants and how they make sense of their experiences, again from their perspectives and views (Richards \& Morse, 2007; cited in Anagün \& Ersoy, 2013).
Phenomenology aims to reveal the essence of the experience by questioning the experiences of individuals regarding the fact/situation/phenomenon (Ersoy, 2019). The phenomenology approach was employed in the study since the study examined the experiences of classroom teachers who just started teaching by interviewing them.

\section{Participants}

Sample selection was determined by using a purposeful sampling method to understand the phenomenon to be examined and to obtain more detailed information about the phenomenon (Creswell, 2007). In this regard, criterion sampling, one of the purposive sampling methods, was utilized in the study to obtain in-depth information about the phenomenon. Within the scope of the research, two basic criteria were taken into account, which is not being in the teaching profession for more than three years and working in schools with different socio-economic levels. A total of 20 interviews were conducted, including classroom teachers from different regions of Turkey. The demographic characteristics of the classroom teachers who participated in the study are presented in Table 1.

Table 1: Demographic Characteristics of the Participating Classroom Teachers

\begin{tabular}{|c|c|c|c|c|}
\hline No & Sex & Age & $\begin{array}{c}\text { First } \\
\text { Teaching } \\
\text { Place }\end{array}$ & $\begin{array}{c}\text { Teaching Grade } \\
\text { Level }\end{array}$ \\
\hline T1 & Male & 24 & Muş & 1st grade \\
\hline T2 & Male & 25 & Iğdır & 4th grade \\
\hline T3 & Female & 29 & Gaziantep & 3rd grade \\
\hline T4 & Male & 29 & Van & Multigrade class \\
\hline T5 & Female & 28 & Yozgat & Multigrade class \\
\hline T6 & Female & 27 & Bitlis & 1st grade \\
\hline T7 & Female & 29 & Aksaray & 2nd grade \\
\hline T8 & Male & 31 & Hakkari & 1st grade \\
\hline T9 & Female & 30 & Niğde & 3rd grade \\
\hline T10 & Male & 29 & Erzincan & 2nd grade \\
\hline T11 & Female & 32 & Kütahya & 3rd grade \\
\hline T12 & Female & 27 & Kütahya & 1st grade \\
\hline T13 & Male & 27 & Adiyaman & Multigrade class \\
\hline T14 & Male & 25 & Adiyaman & Multigrade class \\
\hline T15 & Male & 28 & Diyarbak1r & 3rd grade \\
\hline
\end{tabular}




\begin{tabular}{|c|c|c|c|c|}
\hline T16 & Female & 27 & Ağr1 & 4th grade \\
\hline T17 & Female & 26 & Ağr1 & 2nd grade \\
\hline T18 & Male & 24 & Van & 2nd grade \\
\hline T19 & Female & 28 & Kırıkkale & 3rd grade \\
\hline T20 & Male & 29 & Konya & 1st grade \\
\hline
\end{tabular}

From Table 1, age range of classroom teachers participating in study was 24-32 years. A total of 20 classroom teachers, 10 females \& 10 males working in different regions, participated in study. Four of classroom teachers were teaching at multigrade classes, five taught 1 st grade, four taught 2 nd grade, five taught 3 rd grade, $\&$ two taught 4 th grade.

\section{Data Collection}

Aiming to reveal the experiences of classroom teachers who just started teaching, the study used a semi-structured interview form to collect the data. The interview is a data collection tool where two or more individuals transfer information from one to another for a specific purpose. Verbal and nonverbal communication processes are used, and indepth and rich information is obtained (Bogdan \& Biklen, 2006; McMillian, 2004). Within the scope of the study, the literature was reviewed and an interview form was developed. Then, the semistructured interview form was presented to two experts in the field of elementary school education who had conducted studies with classroom teachers previously. These experts examined the questions in the interview form and gave recommendations regarding the interview questions. According to the views of the field experts, revisions were made in the semi-structured interview form. A classroom teacher was interviewed to determine the functionality of the questions in the finalized semi-structured interview form. Whether the questions in the interview form were understandable or not was decided with this interview. Based on the interview with the classroom teacher, some changes were made to the interview form. The finalized semi-structured interview form was administered to the participating classroom teachers. The interviews were conducted online with the teachers at the times and dates determined by the teachers. The reason for conducting the interviews online was that the classroom teachers participating in the study worked in different cities.

\section{Data Analysis}

Thematic analysis was used in the analysis of the study data. Thematic analysis is used to find, analyze and report the contextual patterns in the data. In thematic analysis, the aim is to describe in-depth the data set by organizing it in the smallest dimensions (Braun \& Clarke, 2019). In this analysis, data are coded, and categories are formed from codes, and themes are formed from categories. In the study, each classroom teacher's views were examined by the researchers, and the codes were formed. In the context of classroom teachers' experiences, categories were formed from codes, and the themes were formed from categories. Findings were presented in line with the data obtained from teachers.

\section{Validity and Reliability}

Some precautions were taken to ensure the validity and reliability of the study. First, to ensure the reliability and validity of the data collection tool, the experts' opinions on the semi-structured interview form were taken before administering the form. A pre-interview was made to determine whether the interview questions were understandable and this interview was not included in the study. Online interviews were recorded to prevent data loss. The interviews lasted between 18 minutes and 42 minutes. At the end of the interviews, the teachers' answers to each question were read back to them and they were asked to confirm the accuracy of their answers. In data analysis, each researcher made a checklist by forming separate codes, categories, and themes from the interview transcripts. Then, the researchers came together and compared their checklists. In case of disagreement in the themes, they reexamined the interview transcripts were examined and a consensus was reached. Direct quotations from teachers' views were presented to support the findings. Codenames were used instead of teachers' real names. The research process was described in detail.

\section{Findings, Results and Discussions}

In the study, which explored the experiences of classroom teachers who are new to the profession, the findings obtained from the data were themed and teacher quotes were included. The themes formed from the findings are presented in Figure 1. 


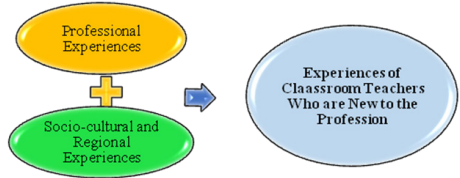

\section{Figure 1: Experiences of Classroom Teachers Who are New to the Profession}

As seen in Figure 1, the study findings were grouped under two themes, namely "Professional experiences" and "Socio-cultural and regional experiences". The "Professional Experiences" of classroom teachers who are new to the profession were divided into three sub-themes, namely "Instructional Experiences," "Experiences with Colleagues," and "Affective Experiences".

Participant T17 stated that the education they received in their undergraduate elementary education program was different from the practice. She said, "My first year in teaching passed with getting used to both my professional life and teaching and the climate and culture of the city where I was. I saw a worldwide difference between the education given at the university and the professional life. I understood that teaching is learned by teaching in the classroom, not by listening to lectures."

T2 stated, "I think that the courses I took at the university were sufficient in terms of subjects, but teaching requires experience, not just knowledge." By stating, "We are not given information about village schools and we start working with zero experience. We learn to teach in the village by experiencing it."

$\mathrm{T} 2$ emphasized that the teaching profession is learned by doing and gaining experience and that they gained awareness on this issue. Similarly, T1 stated that he took more care of the profession and realized that it requires a lot of effort, and explained, "... I felt the need to take care of the students and take more care of the profession. When I got into it, I realized that the teaching profession is a profession that requires more effort." Based on the teachers' quotes, it can be stated that new teachers realize certain situations in the first years of their profession. These are realizing that undergraduate education is only theoretical, practice is more important, the profession requires care and effort, and they gain experience with the practice.
One of the participating teachers, T12, expressed that she communicated with families, held meetings, and organized home visits, and said, "I held parents' meetings because communication with parents is very important. I took the phone numbers of the parents and gave my number to them. I told them they could call me if necessary. I also did home visits. The important element for student education is to know the family." In this context, it can be stated that teachers who just started teaching knew that the family dimension is important for student achievement, and therefore performed some activities to ensure family participation.

The teachers who just started teaching expressed that they faced some instructional situations affecting the learning-teaching process. T8 stated that one of the factors affecting the learning-teaching process was language. On this issue, she said, "... the majority of the people in the East, especially the women, don't know how to speak Turkish because their mother tongue is different. This includes young children who are just starting school. Communication happens through the interpretation of the children in other classrooms. There is a big problem in communication when there is a home visit or when they come to the school." Also, some teachers expressed that one of the factors affecting the learning-teaching process was the indifference of families and students' absenteeism.

Related to this, T7 said, "Since it was a village, there were problems such as lack of interest from parents, not valuing their children, and students not coming to school." In addition, by saying, "The school administration certainly didn't support us. They even prevented activities we wanted to do with children. Likewise, I didn't receive any support from the Provincial Directorate for National Education." T10 mentioned that they did not receive support from the school and provincial administrators and even encountered obstacles. Based on teacher quotations, it can be stated that teachers who just started teaching are faced with situations negatively affecting their teaching-learning processes. Not getting enough support from parents of the students and school and provincial administrators stand out among these problems. 
Teachers who just started teaching also had certain experiences with their colleagues. T3 said, "...there were five classrooms in the school where I was appointed; there were four more teachers with me. I wasn't alone. This made me very happy. I went to the village thinking that I would be bored, but the friendships I formed with my colleagues continue."

On the same issue, T2 said, "When I was appointed to the village, I talked to my friends from I $\breve{g} d ı$ who worked there before me. I got ideas and information from them. They helped a lot." Based on teachers' views, it can be said that other teachers helped the teacher who has just started teaching in the village and that the teachers supported each other.

Another teacher, T13, mentioned that he liked teaching even more after starting teaching and said, "I thought I liked the profession I chose even more after starting. I could never do any profession other than teaching." Another teacher (T1) talked about professional satisfaction and said, “... the experiences I gained when I started teaching helped me achieve professional satisfaction."

In addition, S14 talked about how he was surprised by some situations when he first started teaching and how these become normal later on. He explained, "My first year was better than I expected. I encountered people who could be happy with small things. I was surprised at first, but then this situation came to be normal." Also, a teacher (T8) mentioned how he looked at events more realistically after he started teaching and said, “.... your point of view becomes clearer. You look at events and facts more realistically."

Finally, T2 talked about how his prejudices about his profession were gone and how he was proud of his profession now, and said, "I used to think teaching wasn't a match for me, but now I am grateful for choosing this profession. My negative on the profession changed, my prejudices are gone. I love my job and I am proud."

The participating teachers who just started teaching also talked about their socio-cultural experiences related to the region they worked in. The Socio-Cultural and Regional Experiences of the teachers who just started teaching were divided into two subthemes, namely "Regional Characteristics" and "Characteristics of the Region's People." One of the participating teachers (T4) talked about finding a vehicle to go from the village to the city center. There were problems with resources such as the internet, telephone, and electricity. He explained, "It is very difficult to find a vehicle to go to the district. So many times I had to walk from town to village... $(27 \mathrm{~km})$. It is difficult to explain, to put into words. Our water froze in winter; we brought water from a distant place for 40 days with canisters. We lived without electricity for up to 20 days. Phone and internet are, of course, one of the biggest problems of the East."

Similarly, T1 stated that there was no social life and opportunities in the village where he worked and said, "Actually, you are disappointed when your expectations are high. The village we are in is unfortunately far from the district center of Bulanik. We can only go on weekends. In this regard, I can say that I am having difficulties, actually, great difficulties. When I lived in the center, my opportunities and social life were not limited." Based on teachers' views, it can be said that teachers are deprived of social life and some resources and opportunities due to the nature of the region.

Despite these negative characteristics of the region, one of the teachers (T18) said, "The first day I went to school, the village representative came to the school and said that I was invited to their house for lunch. I said to myself, great. Of course, I was surprised when I saw the bulgur pilaf and ayran (a drink made with yogurt and water) at lunch. So, there were people who shared their food without hesitation even if there was only rice and ayran at home." T19 and T4 talked about how the people of the region were sincere, respectful, and helpful.

On this issue, T19 said, “... There is an incredible respect for teachers here. And that's the most beautiful thing that connects us here." Similarly, T4 said, "I had to deal with every kind of problem, but it is enough for me that people are sincere and candid. Their love for teachers can't be explained." In addition, another teacher (T4) mentioned how the education level of the region's people was low and said, "Unfortunately, I am in an underdeveloped region in terms of education. Many of my parents are illiterate and I had a hard time because of this." The present study revealed that the participating 
teachers who recently started teaching had certain experiences due to the regions they worked at and due to their first year of teaching. Some of these experiences were positive and some were negative. It can be stated that these experiences contributed to them both professionally and personally.

The teachers stated that when they started teaching, they realized that subject knowledge was not enough just by itself, and there were deficiencies in practice. In this regard, teachers expressed that they learned the profession better by experiencing the profession and realized that the teaching profession requires care and effort. Similarly, in Aydın and Şahin's (2020) study, classroom teachers who were new to the profession stated that they had taken a course on classroom management. Still, they felt inadequate, especially in maintaining classroom order when they started teaching. Teachers do not have confidence in themselves when they are newly appointed (Korkmaz, et al., 2004) and generally consider themselves inexperienced and inadequate in professional knowledge and competence (Delican \& Sönmez, 2020). Melnick \& Meister (2008) revealed a clear disconnect between preservice teachers' personal beliefs and attitudes on teaching and the realities of the classroom. However, teachers stated that obstacles such as the indifference of families, children's absenteeism, and language problems negatively affected the learning-teaching process and that they could not get support from the authorities. As Duran, et al., (2011) stated in their study, effective work of the directors of the district and provincial directorate of national education to meet the needs of teachers will be beneficial in overcoming the problems teachers encounter and helping teachers not feeling alone.

Similarly, in their study, Anılan, et al., (2015) put forth that teachers who starter working in rural areas faced problems such as crowded classrooms, lack of materials and technology, the curriculum not taking into account the characteristics of rural areas, parents' indifference, parents' low education levels, and students' indifference to the lessons. Aydın and Şahin (2020) concluded in their study that classroom teachers who just started their profession communicate with the family to restore order in the classroom. On the other hand, the study conducted by Öztürk (2016) revealed that teachers who were in their first year of teaching did not experience a lot of problems in their relations with their students, parents, and colleagues. He stated that this is a positive situation in terms of adjusting the new teachers to the profession. In this context, it can be said that the experiences of teachers who just started teaching help them develop positive attitudes towards the teaching profession. Korkmaz, et al., (2004) expressed that the support given to teachers who just started teaching by their experienced colleagues and principals positively affects their retention and success.

The teachers stated that they got support from their more experienced colleagues and this support made them love the profession even more. Similarly, Beck, et al., (2007) stated that while teachers struggled with the implementation process in their early years, there was no reduction in their adherence to the constructivist education and child-centered ideas they received pre-service programs. According to Duran, et al., (2011), teachers encounter important problems related to adjustment to the social life and institutional culture of the environment they are appointed to and organizational socialization. For teachers who just started their profession, schools should provide teachers with professional development opportunities and a social environment that teachers enjoy working in. Teachers who are welcomed in the school environment form a long-lasting bond with the school (Sargent 2003). Most particularly, they emphasized that intensive theoretical knowledge and education beyond reality are offered in teaching training programs (DarlingHammond \& Bransford, 2005; Labaree, 2004). To best assist teachers as they prepare for their first year (and subsequent years), we as teacher educators should support our teacher candidates by building a bridge between theory and practice. In the education process, few subjects can be taught with a more indepth application (Beck, et al., (2007). The education received by teachers in their teacher training programs consists mainly of theoretical courses. In this sense, the course contents in the faculties of education can be structured towards practice. In addition, the teaching practice courses can include practice in rural schools. 


\section{Conclusion}

Aiming to reveal the experiences of classroom teachers in their first years, the study determined that teachers expressed their experiences in the context of "professional experiences" and "socioculturalregional experiences." In the context of professional experience, classroom teachers pointed out that there was a difference between the pre-service education they got and the real. They talked about the differences between theoretical knowledge and practice.

In this study, it was determined that teachers used communication means such as house visits and parents' meetings to ensure family participation in the learning process. They also emphasized the importance of communication with the family since the most important thing in solving students' behaviors that disrupt the classroom order is learning the reason for that behavior. Considering that school life is a whole with the culture and social life of the society, it was seen that teachers have problems in management and that they can adjust to this situation and solve their problems by gaining experience.

In the context of sociocultural experience, classroom teachers mentioned that they had problems in terms of transportation and communication due to the characteristics of the region and talked about the negative effects of these problems on their social lives. Although most people in the regions where they taught were illiterate, their approach to teachers was sincere and candid. Studies revealed that many teachers and teacher candidates believe that preservice preparations are inadequate in some respects.

\section{References}

Anagün, S., and A. Ersoy. "Nitel Araştırma Yöntemleri.” Bilimsel Araştırma Yöntemleri. Edited by Savaş Baştürk, Vize Yayıncılık, 2013, pp. 375-415.

Anılan, Hüseyin, et al. "Become Teachers in Rural Areas: Perspective of Classroom Teachers." Turkish Studies, vol. 10, no. 11, 2015.

Aydın, Şeyma, and Ali Ekber Şahin. "Practices of Beginning Primary School Teachers in Dealing with Restoring Order in Classroom." Mersin University Journal of the Faculty of Education, vol. 16, no. 2, 2020, pp. 363-381.
Barley, Zoe A. "Preparing Teachers for Rural Appointments: Lessons from the MidContinent." The Rural Educator, vol. 30, no. 3, 2009, pp. 10-15.

Beck, Clive, et al. "Preparation for the First Year of Teaching: Beginning Teachers' Views about their Needs." The New Educator, vol. 3, no. 1, 2007, pp. 51-73.

Bogdan, Robert, and Sari Knopp Biklen. Qualitative Research For Education: An Introduction to Theory and Methods. Pearson, 2006.

Braun, Virginia, and Victoria Clarke. "Psikolojide Tematik Analizin Kullanımı." Journal of Qualitative Research in Education, vol. 7, no. 2, 2019, pp. 873-898.

Britt, Patricia M. "Perceptions of Beginning Teachers: Novice Teachers Reflect upon Their Beginning Experiences." Annual Meeting of the Mid-South Educational Research Association, 1997.

Brock, Barbara L., and Marilyn L. Grady. From First-Year to First-Rate: Principals Guiding Beginner Teachers. Corwin Press, 2007.

Carter, Kathy, and Walter Doyle. "Preconceptions in Learning to Teach." The Educational Forum, vol. 59, no. 2, 1995, pp. 186-195.

Casey, Catherine E. The Relationships among Teacher Education Admission Criteria, Practice Teaching, and Teacher Candidate Problems. University of Toronto, 2005.

Creswell, John W. Research Design Qualitative, Quantitative and Mixed Methods Approaches. Sage Publications, 2009.

Darling-Hammond, Linda, and John Bransford. Preparing Teachers for a Changing World: What Teachers Should Learn and Be Able to Do. John Wiley, 2005.

Deal, Terrence E., and Reva M. Chatman. "Learning the Ropes Alone: Socializing New Teachers." Action in Teacher Education, vol. 11, no. 1, 1989, pp. 21-29.

Delican, Esra, and Ömer Faruk Sönmez. "The First Experiences of Newly Appointed Primary Education Teachers." Uluslararasl Türk Kültür Coğrafyasında sosyal Bilimler Dergisi, vol. 5, no. 2, 2020, pp. 125-151. 
Denscombe, Martyn. Classroom Control: A Sociological Perspective. George Allen \& Unwin, 1985.

Duran, Erol, et al. "Examining Candidate Classroom Teachers' Compliance and Socialization Process." Dumlupınar Üniversitesi Sosyal Bilimler Dergisi, vol. 31, 2011, pp. 465-478.

Eaton, Elizabeth, and Wendy Sisson. Why are New Teachers Leaving? The Case for BeginningTeacher Induction and Mentoring. ICF International, 2008.

Eppley, Karen. "Rural Schools and the Highly Qualified Teacher Provision of No Child Left Behind: A Critical Policy Analysis." Journal of Research in Rural Education, vol. 24, no. 4, 2009, pp. 1-11.

Ersoy, Ali. "Fenomenoloji." Eğitimde Nitel Araştırma Desenleri. Edited by Ahmet Saban and Ali Ersoy, Anı Yayıncılık, 2019, pp. 82-138.

Feiman-Nemser, Sharon. "What New Teachers Need to Learn?.” Educational Leadership, vol. 60, no. 8, 2003, pp. 25-29.

Fideler, Elizabeth, and David Haskelhorn. Learning the Ropes: Urban Teacher Induction Programs and Practices in the United States. Recruiting New Teacher, 1999.

Fry, Sara Winstead, and H. Anderson. "Career Changers as First-Year Teachers in Rural Schools." Journal of Research in Rural Education, vol. 26 , no. 12, 2011, pp. 1-16.

Gold, Yvonne, et al. "The Relationship of Scores on the Educators Survey, A Modified Version of the Maslach Burnout Inventory, to Three Teaching-Related Variables for a Sample of 132 Beginning Teachers." Educational and Psychological Measurement, vol. 51, no. 2, 1991, pp. 429-438.

Gonzalez, LuzE., and Kathy Carter. "Correspondence in Cooperating Teachers' and Student Teachers' Interpretations of Classroom Events." Teaching \& Teacher Education, vol. 12, no. 1, 1996, pp. 39-47.

Grissmer, David Waltz, and Sheila Nataraj Kirby. Teacher Attrition: The Uphill Climb to Staff the Nation's Schools. Rand Corporation, 1987.
Grissmer, David Waltz, and Sheila Nataraj Kirby. "Teacher Turnover and Teacher Quality." Teachers College Record, vol. 99, no. 1, 1997, pp. 45-56.

Ingvarson, Lawrence, et al. "Factors Affecting the Impact of Teacher Education Programmes on Teacher Preparedness: Implications for Accreditation Policy." European Journal of Teacher Education, vol. 30, no. 4, 2007, pp. 351-381.

Jacques, Kate. "Solicitous Tenderness: Discipline and Responsibility in the Classroom." Children's Perceptions of Learning with Trainee Teachers. Edited by Hilary Cooper, and Rob Hyland, Routledge, 2000.

Johnson, Susan Moore, and Sarah E. Birkeland. "Pursuing a "Sense of Success": New Teachers Explain Their Career Decisions." American Educational Research Journal, vol. 40, no. 3, 2003, pp. 581-617.

Kauffman, David, et al. "Lost at Sea": New Teachers' Experiences with Curriculum and Assessment." Teachers College Record, vol. 104, 2002.

Korkmaz, İsa, et al. "Professional Challenges Encountered by Beginning Classroom Teachers." Educational Administration in Theory and Pracitce, vol. 38, 2004.

Labaree, David. The Trouble with Ed Schools. Yale University Press, 2004.

Lacey, Paul A. "Faculty Development and the Future of College Teaching." College Teaching and Learning: Preparing for New Commitments, no. 33,1988 , pp. 57-69.

Ladd, K. "A Comparison of Teacher Education Programs and Graduate's Perceptions of Experiences." Dissertation Abstracts International, 2000.

Lortie, Dan. Schoolteacher: A Sociological Study. University of Chicago Press, 1975.

Lowe, Jerry M. "Rural Education: Attracting and Retaining Teachers in Small School." Rural Educator, vol. 27, no. 2, 2006, pp. 28-32.

McCracken, J. David, and Charles Miller. "Rural Teachers' Perceptions of Their Schools and Communities." Research in Rural Education, vol. 5 , no. 2, 1988, pp. 23-26. 
Mcmillan, James H. Educational Research: Fundamentals for the Consumer. Pearson Education, 2004.

Melnick, Steven A., and Denise G. Meister. "A Comparison of Beginning and Experienced Teachers' Concerns." Educational Research Quarterly, vol. 31, no. 3, 2008, pp. 40-56.

Öztürk, Mustafa. "Induction Challenges Experienced by Novice Teachers Teaching in Villages and Small Towns." Elementary Education Online, vol. 15 , no. 2, 2016, pp. 378-390.

Sargent, Barbara. "Finding Good Teachers - And Keeping Them." Educational Leadership, vol. 60 , no. 8 , 2003, pp. 44-47.

Sarıtaş, Mustafa. "Evaluation of the Opinions about the Benefits of the Application of Experience to the Teachers Candidates." Eğitim Fakülktesi Dergisi, vol. 20, no. 1, 2007, pp. 121-143.

Savage, Tom V., and Marsha K. Savage. Successful Classroom Management and Discipline Teaching Self-Control and Responsibility. Sage Publications, 2010.

Smith, Thomas M., and Richard M. Ingersoll. "What are the Effects of Induction and Mentoring on Beginning Teacher Turnover?" American Educational Research Journal, vol. 47, no. 3, 2004, pp. 681-714.

Varrella, Gary F. "Science Teachers at the Top of Their Game: What is Teacher Expertise?" The Clearing House: A Journal of Education Strategies, Issues and Ideas, vol. 74, no. 1, 2000, pp. 43-46.

Veenman, Simon. "Perceived Problems of Beginning Teachers." Review of Educational Research, vol. 54, no. 2, 1984, pp. 143-178.

Wyatt, Robert L., and Joyce Elaine White. Making Your First Year a Success: A Classroom Survival Guide for Middle and High School Teachers. Sage Publication, 2007.

Yıldırım, Ali, and Hasan Şimşek. Sosyal Bilimlerde Araştirma Yöntemleri. Seçkin Yayınları, 2011.

Zeichner, Kenneth M., and B. Robert Tabachnick. "The Development of Teacher Perspectives: Social Strategies and Institutional Control in the Socialization of Beginning Teachers." Journal of Education for Teaching, vol. 11, no. 1, 2006, pp. 1-25.

\section{Author Details \\ Zeynep Kılıç, Faculty of Education, Eskişehir Osmangazi University, Eskişehir, Turkey, \\ Email ID: zeyno-dev@hotmail.com.}

Nurhan Atalay, Faculty of Education, Niğde Ömer Halisdemir University, Niğde, Turkey,

Email ID: nurratalay@gmail.com.

Burcu Anılan, Faculty of Education, Eskişehir Osmangazi University, Eskişehir, Turkey,

Email ID: anilan.burcu@gmail.com.

Şengül, S. Anagün, Faculty of Education, Eskişehir Osmangazi University, Eskişehir, Turkey,

EmailID: ssanagun@gmail.com.

Hüseyin Anılan, Faculty of Education, Eskişehir Osmangazi University, Eskişehir, Turkey,

Email ID: anilan.huseyin@gmail.com. 